\title{
RAPID LABORATORY DIAGNOSIS OF LUMPY SKIN DISEASE BY USING PCR TECHNIQUE
}

\author{
KHALED A.S. EL-KHABAZ \\ Department of Animal Medicine (Infectious Diseases), Faculty of Veterinary Medicine, Assiut University, Egypt. \\ E-mail: khaledsayed_1970@yahoo.com
}

\section{ABSTRACT}

Received at: 9/8/2014

Since the first report of lumpy skin disease occurrence in Egypt, frequent outbreaks of the disease occur irregularly in different localities of Egypt. During the late summer Accepted: 21/10/2014 and fall months of 2013 many cases suffering from clinical signs of lumpy skin disease were recorded in Assiut governorate-Egypt, from which 21 animals (3 vaccinated and 18 non-vaccinated) were used in this study to ascertain the clinical diagnosis by the polymerase chain reaction (PCR). Fifteen skin intradermal biopsies and 6 blood samples were subjected to the PCR technique using specific primer for viral attachment protein encoding gene of lumpy skin disease virus (LSDV). All the tissue samples gave positive results while the blood samples were negative.

Key words: LSD, capripoxvirus, PCR, outbreaks, cattle, Egypt, Assiut.

\section{INTRODUCTION}

Lumpy skin disease (LSD) is a pox disease of cattle characterised by fever, nodules on the skin, mucous membranes and internal organs, emaciation, enlarged lymph nodes, oedema of the skin, and sometimes death (OIE, 2010). Lumpy skin disease virus (LSDV), the etiologic agent of LSD, is a member of the capripoxvirus genus of the Poxviridae family (Tulman et al., 2001).

LSD has a major economic importance as it may cause temporary or permanent infertility, cost of control and eradication measures (Tuppurainen and Oura, 2012), reduced milk yield and sometimes death due to secondary bacterial infections (Chihota et al., 2003). In addition, it disrupts the trade in cattle and their products from LSD endemic countries (Babiuk et al., 2008). Deep skin lesions leave permanent scars and decrease the value of hide (Green, 1959).

Transmission of the disease occur primarly by biting flies and mosquitoes (Chihota et al., 2001). Molecular evidence suggesting that LSD can be transmitted through hard (Ixodid) ticks (Tuppurainen et al., 2011).

Laboratory confirmation of LSD using a polymerase chain reaction (PCR) method specific for capripoxviruses is most rapid, sensitive and specific (OIE, 2010; Raof et al., 2010 and El-Kenawy and ElTholoth, 2011). PCR is the test of choice for rapid detection and identification of the causative agent of LSD (El-Nahas et al., 2011).
The real danger of the disease lies in the fact that it has continued to spread, extending its range to include all of Africa, with infrequent appearances in the Middle East (Woods 1988). Further spread of LSD into Asia (east) and Europe (north) through Middle East and Turkey is possible (Tuppurainen and Oura, 2012).

The first report of lumpy skin disease occurrence in Egypt was in May 1988 in Suez and Ismailia governorates after importation of live cattle from Somalia (House et al., 1990). In early 2006, a severe LSD outbreak struck foreign (imported from Ethiopia) and local cattle in different Egyptian governorates, causing enormous economic losses (ElKholy et al., 2008 and Sharawi and Abd El-Rahim, 2011). Also in 2010 an outbreak of LSD was recorded in Ismailia governorate (Raof et al., 2010).

The aim of this work is to ascertain the clinical diagnosis and determine the real cause of such outbreak by using PCR technique, as a rapid and sensitive diagnostic tool, in order to apply the suitable control measures.

\section{MATERIALS and METHODS}

\section{Animals:}

The study was carried out in Assiut governorate which is one of the upper Egypt governorates.

Large number of cattle with clinical signs suggesting its infection with LSDV were examined clinically during the period from September till December 2013 
and from these animals, samples were collected from different 21 cattle ( 3 of them were vaccinated by sheep pox virus vaccine and the rest were nonvaccinated), of different ages, sexes and from different localities of Assiut governorate.

\section{Clinical examination:}

a- Non-vaccinated animals:

The animals in this group were suffering from different clinical signs such as fever (40.5-41 ${ }^{\circ} \mathrm{C}$ ), appearance of multiple intradermal skin nodules which may be sloughed leaving deep ulcers, edema in fore limbs, enlargement of superficial lymph nodes especially prescapular and precuraral, and respiratory distress (Figures $1 \& 2$ ).

\section{b- Vaccinated animals:}

Signs in this group were milder than in nonvaccinated group as the temperature reaction is about (39.5-40 ${ }^{\circ} \mathrm{C}$ ) and appearance of few intradermal skin nodules.

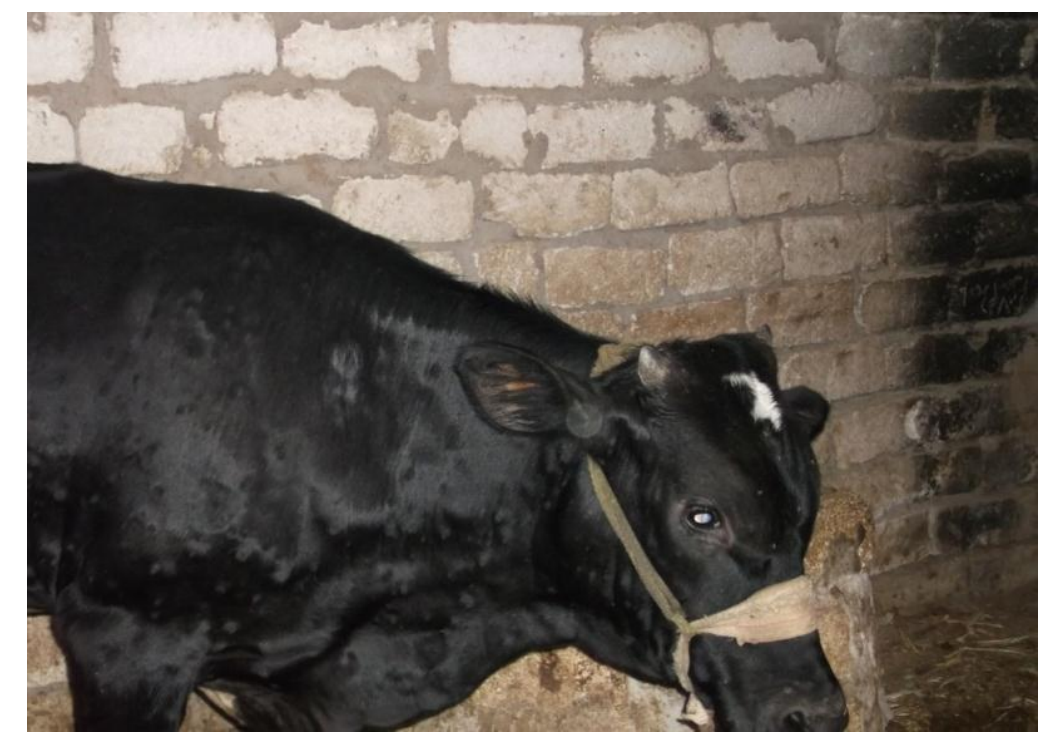

Figure 1: Appearance of multiple intradermal skin nodules

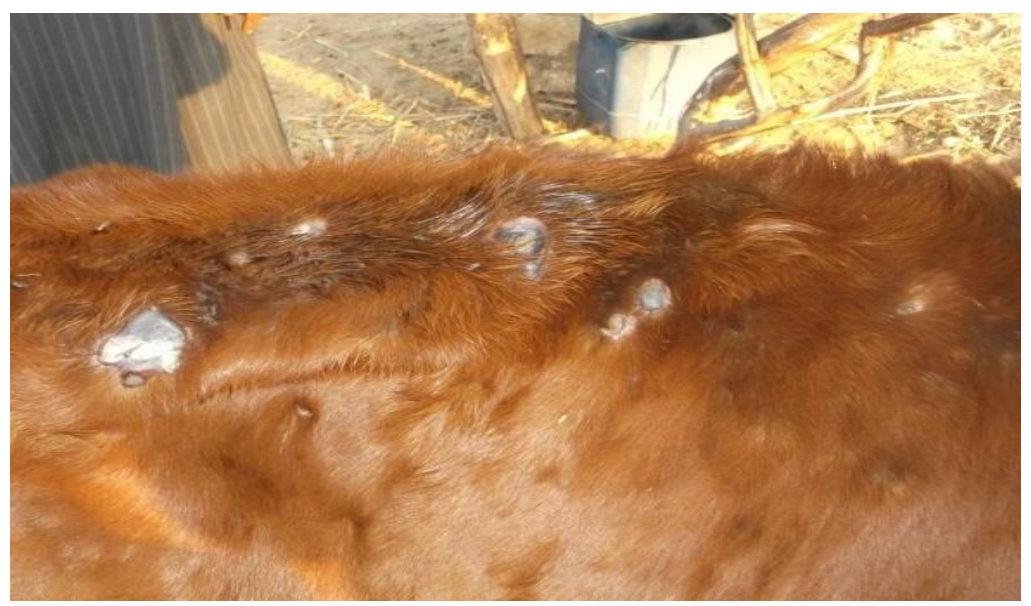

Figure (2): Intradermal nodules with sloughing of some nodules leaving ulcers

\section{Samples:}

\section{1- Skin nodules biopsies:}

Under complete aseptic condition and local anaesthia (Debocaine, lidocaine $\mathrm{HCl} 2 \%$, Al-Debeiky pharma A.R.E.) 15 biopsies of the nodular skin lesions, from different 15 animals (12 non-vaccinated and 3 vaccinated), comprising epidermis, dermis and subcutis were surgically collected and preserved at $-80^{\circ} \mathrm{C}$ and the resultant wounds were sutured.

\section{2- Blood samples:}

Under complete aseptic condition 6 blood samples from different non-vaccinated animals were collected in vacutainer sterile tubes containing EDTA and preserved in $-80^{\circ} \mathrm{C}$. 
PCR technique:

\section{DNA extraction:}

DNA extractions either from skin nodules or blood were done using QIAamp DNA Mini Kit (Cat No. 52904, Lot No. 142340050) - Qiagen GmbH. The extraction process was done according to the instruction of the kit.

\section{Primers:}

The PCR primers were developed from the viral attachment protein encoding gene (Ireland and Binepal 1998) designated by Invitrogen life technologies and have the following sequence:

Forward primer 5'- TTTCCTGATTTTTCTTACTAT 3'

Reverse primer 5'- AAATTATATACGTAAATAAC 3'

The size of the amplicon was 192 bp (Ireland and Binepal 1998).

A GoTaq Green Master Mix 2x (Promega) was used for amplification of nucleic acid templates. DNA amplification was carried out in a final volume of 25 $\mu \mathrm{l}$ containing $12.5 \mu \mathrm{l}$ GoTaq Green Master Mix (2x), $1 \mu 110 \mathrm{pM}$ each primer, $8.5 \mu \mathrm{l}$ PCR grade water and $2 \mu \mathrm{l}$ DNA sample.
The reaction was carried out in $\mathrm{T}$ professional thermocycler Basic Biometra according to Ireland and Binepal (1998) with modification. The PCR started with one cycle of $94{ }^{\circ} \mathrm{C}$ for $10 \mathrm{~min}$. This was followed by 43 cycles of $94^{\circ} \mathrm{C}$ for $1 \mathrm{~min}, 44^{\circ} \mathrm{C}$ for 30 $\mathrm{s}$, and $72^{\circ} \mathrm{C}$ for $1 \mathrm{~min}$. and a final elongation step of $72{ }^{\circ} \mathrm{C}$ for $1 \mathrm{~min}$ to complete the extension of the primers. Negative control samples also included when testing the samples by the PCR. Amplified products were analysed using a 100 bp DNA ladder (Nippon Genetics Europe $\mathrm{GmbH}$ ) as a molecular marker on $1.5 \%$ agarose gels. Gels were stained using ethidium bromide $(1 \mu \mathrm{g} / \mathrm{ml})$ in Tris EDTA (TE) and amplicons were visualized using an UV transilluminator (documentation system Viber 104 mat) at a wave length of $590 \mathrm{~nm}$. Positive reactions were confirmed according to size.

\section{RESULTS}

Viral attachment protein encoding gene primers were used for PCR analysis of extracted DNA of the clinical samples (15 skin biopsies and 6 EDTA blood samples) by agarose gel electrophoresis.

The expected amplicon size of (192 bp) was found in all skin biopsies from both vaccinated and nonvaccinated animals (Figure 3), while can't be detected in any of EDTA blood samples.

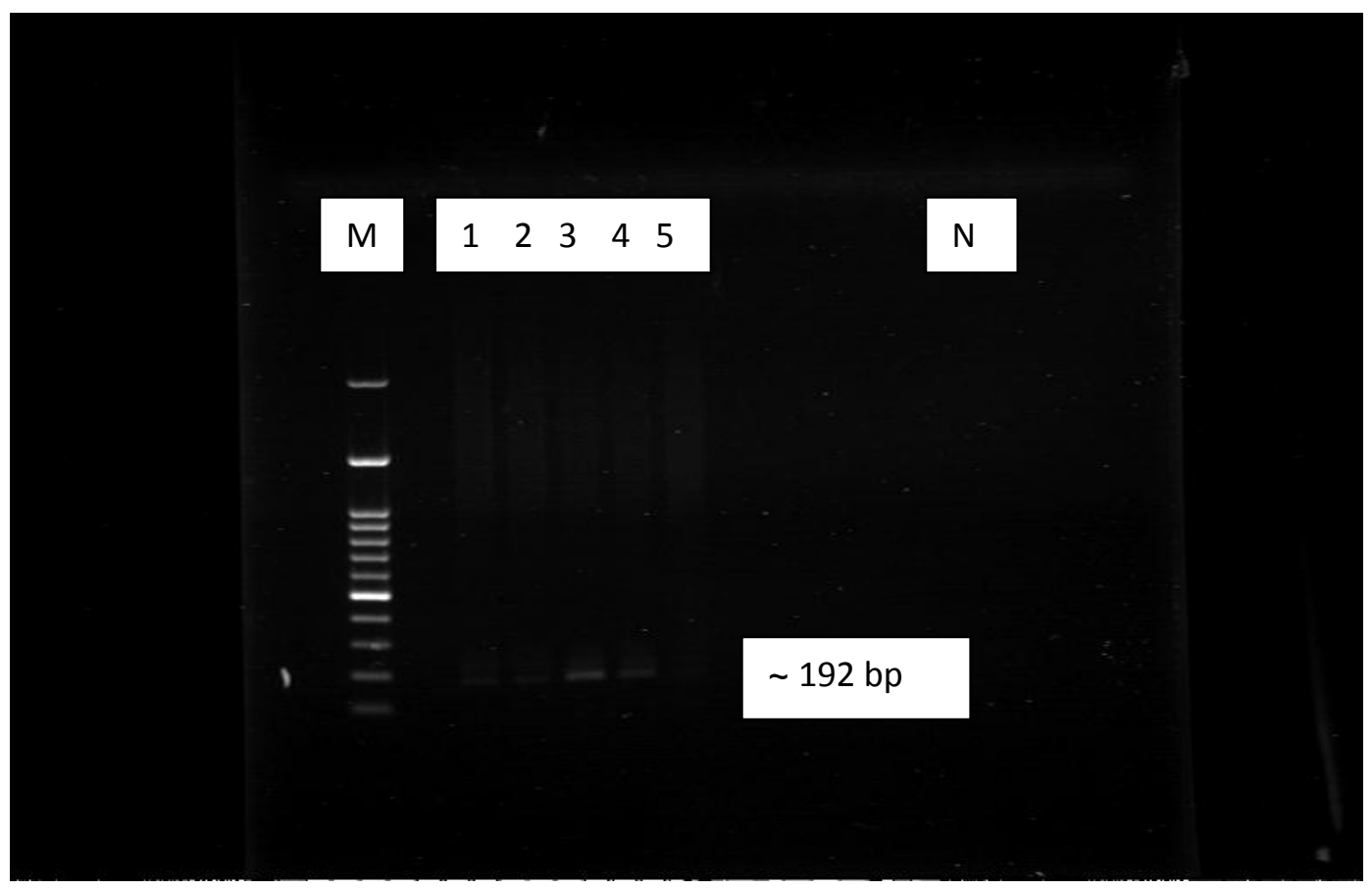

Figure (3): $\quad$ M : 100 bp ladder marker

1-5 : skin samples with the obtained bands at $\sim 192 \mathrm{bp}$ as expected

$\mathbf{N}$ : control negative 


\section{DISCUSSION}

The affected cases began with fever, anorexia, edema of fore limbs, skin nodules all over the body which may be in severe cases slough leaving deep ulcers. Respiratory distress, corneal opacity and death were also recorded in some cases. The associated clinical signs were also described by (House et al., 1990, Hunter and Wallace, 2001, Sharawy and Abd ElRahim, 2011 and Body et al., 2012).

Concerning the frequent occurrence of the disease in different governorates of Egypt especially in summer and fall months, it may be due to the increased insect population during such period, also the disease quiescence is probably due to unfavorable climatic conditions that reduce vector prevalence, with a concomitant reduction of the host immunity that later result in extensive outbreaks (Hunter and Wallace, 2001). LSDV was isolated in Egypt from naturally infected water buffaloes which indicate that the virus circulate and maintained in such species of animals (El-Nahas et al., 2011 and Sharawi and Abd ElRahim, 2011) so buffaloes seem to be playing an important role in appearance of these outbreaks of LSD.

In the current study the high sensitivity of PCR $(100 \%)$ in detecting the LSDV DNA in skin nodular samples correlate very well with (Tuppurainen et al., 2005, El-Kholy et al., 2008, Sharawi and Abd ElRahim, 2011 and ElHaig et al., 2013) and this may be attributed to the viral tropism to skin tissues and its persistence in high concentration.

The 3 vaccinated animals (by sheep pox virus vaccine) were found to be positive with PCR, this may give an alarm for the need of a large scale study to judge and evaluate the efficiency of such vaccine at present time. However it may be more beneficial to use a vaccine prepared from LSDV in disease controlling programs. This results agree with (Salib and Osman 2011) who mentioned that sheep pox virus vaccine could not protect Egyptian cattle against LSD. Also $5 \%$ of vaccinated cattle with live attenuated sheep and goat pox vaccine (Kenya strain, KS1) developed clinical signs of the LSD (Tageldin et al., 2014).

The failure of PCR to detect LSDV DNA in any of the 6 EDTA blood samples may be attributed to that the samples collected later in the course of the disease as the owners of these animals refuse the skin biopsy technique in collecting the samples. Also it may be due to the presence of the virus in blood at low level and for short period (Carn and Kitching, 1995), also PCR was negative for blood samples collected 15 days post infection (Tuppurainen et al., 2005). The low sensitivity of PCR in detecting LSDV DNA in EDTA blood was also noticed by (ElHaig et al.,
2013) who mentioned that the sensitivity of PCR in such case was $40 \%$.

In conclusion, whenever suspected cases of LSD appear the application of PCR technique, especially on skin biopsies samples, as a rapid and accurate diagnostic tool is very important and helpful in order to reach the correct diagnosis and applying the suitable and adequate control measures. Because the use of sheep pox virus vaccine doesn't prevent the infection, the Egyptian control strategy which depends upon the use of such vaccine must be changed and replaced by vaccine prepared from LSDV.

\section{REFERENCES}

Babiuk, S.; Bowden, T.R.; Boyle, D.B.; Wallace, D.B. and Kitching, R.P. (2008): Capripoxviruses: An emerging worldwide threat to sheep, goats and cattle. Transboundary and Emerging Disease. 55: 263-272

Body, M.; Singh, K.P.; Hussain, M.H.; Al-Rawahi, A.; Al-Maawali, M.; Al-Lamki, K. and AlHabsy, S. (2012): Clinico-Histopathological findings and PCR based diagnosis of lumpy skin disease in the Sultanate of Oman. Pak Vet J. 32(2): 206-210.

Carn, V.M. and Kitching, R.P. (1995): The clinical response of cattle experimentally infected with lumpy skin disease (Neethling) virus. Archives of virology. 140(3): 503-513.

Chihota, C.M.; Rennine, L.F.; Kitching, R.P. and Mellor, P.S. (2001): Mechanical transmission of lumpy skin disease virus by Ades aegypti (Diptera.: Culicidae). Epidemiol Infect. 126: 317-321.

Chihota, C.M.; Rennine, L.F.; Kitching, R.P. and Mellor, P.S. (2003): Attempted mechanical transmission of lumpy skin disease virus by biting insects. Medical Veterinary Entomology. 17: 294-300.

Elhaig, M.M.; Selim, A. and Shahira, A. (2013): Polymerase chain reaction and dot blots hybridization techniques for diagnosis of lumpy skin disease in cattle in Egypt. Jökull journal. 63(6): 208-216

El-Kenawy, A.A. and El-Tholoth, M.S. (2011): Lumpy skin disease virus identification in different tissues of naturally infected cattle and chorioallantoic membrane of emberyonated chicken eggs using immunofluorescence, immunoperoxidase techniques and polymerase chain reaction. International journal of virology. 7 (4): 158-166.

El-Kholy, A.A.; Soliman, H.M.T. and Abdelrahman, K.A. (2008): polymerase chain reaction for rapid diagnosis of a recent lumpy skin disease virus incursion to Egypt. Arab J. Biotech. 11(2): 293-302. 
El-Nahas, E.M.; El-Habbaa, A.S.; El-Bagoury, G.F. and Radwan, Mervat, E.I. (2011): Isolation and identification of lumpy skin disease virus from naturally infected buffaloes at Kaluobia, Egypt. Global Veterinaria, 7(3): 234-237.

Green, H.F. (1959): Lumpy skin disease: its effect on hides and leather and a comparison on this respect with some other skin diseases. Bull. Epizoot. Dis. Afr. 7, 63.

House, J.A.; Wilson, T.M.; El Nakashly, S.; Karim, I.A; Ismail, I.; El Danaf, N.; Moussa, A.M. and Ayoub, N.N. (1990): The isolation of lumpy skin disease virus and bovine herpesvirus from cattle in Egypt. J. Vet. Diagn. Invest., 2: 111-115.

Hunter, P. and Wallace, D. (2001): Lumpy skin disease in southern Africa: a review of the disease and aspects of control. Journal of the South African Veterinary Association, 72(2): 68-71.

Ireland, D.C. and Binepal, Y.S. (1998): Improved detection of capripoxvirus in biopsy samples by PCR. journal of virological methods, 74 : $1-7$.

OIE (2010): Lumpy skin disease. In: OIE Terrestrial Manual. Paris: World Organization for Animal Health (OIE) 2010; chapter 2.4.14: 1-13.

Raof, Amal, M.A.; Saad, A.A. and Ahmed, Lamia, A. (2010): Use of a polymerase chain reaction assay to detect lumpy skin disease virus (LSDV) in skin lesions of cattle. Epypt. J. Comp. Path., 23(1): 116-126.

Salib, F.A. and Osman, A.H. (2011): Incidence of lumpy skin disease among Egyptian cattle in Giza governorate, Egypt. Veterinary world 4(4): 162-167.
Sharawi, S.S.A. and Abd El-Rahim, I.H.A. (2011): The utility of polymerase chain reaction for diagnosis of lumpy skin disease in cattle and water buffaloes in Egypt. Rev. sci. tech. Off. Int. Epiz. 30(3): 821-830.

Tageldin, M.H.; Wallace, D.B.; Gerdes, G.H.; Putterill, J.F.; Greyling, R.R.; Phosiwa, M.N.; Al Busaidy, R.M. and Al Ismaaily, S.I. (2014): Lumpy skin disease of cattle: an emerging problem in the Sultanate of Oman. Trop Anim Health Prod. 46: 241-246.

Tulman, E.R.; Afonso, C.L.; Lu, Z.; Zsak, L.; Kutish, G.F.; and Rock, D.L. (2001): Genome of Lumpy Skin Disease Virus. Journal of virology, 75(15): 7122-7130.

Tuppurainen, E.S.M.; Venter, E.H. and Coetzer, J.A.W. (2005): The detection of lumpy skin disease virus in samples of experimentally infected cattle using different diagnostic techniques. Onderstepoort J. Vet. Res. 72: 153-164.

Tuppurainen, E.S.M.; Stoltz, W.H.; Troskie, M.; Wallace, D.B.; Oura, C.A.L.; Mellor, P.S.; Coetzer, J.A.W. and Venter, E.H. (2011): A potential role for Ixodid (hard) tick vectors in the transmission of lumpy skin disease virus in cattle. Transbound. Emerg. Dis. 58: 93-104.

Tuppurainen, E.S.M. and Oura, C.A.L. (2012): Review: Lumpy Skin Disease: An Emerging Threat to Europe, the Middle East and Asia. Transboundary and Emerging Diseases. 59: 40-48.

Woods, J.A. (1988): Lumpy skin disease-A review. Tropical Animal Health and Production. 20: 11-17.

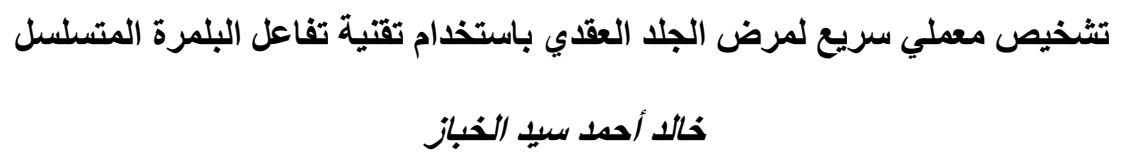

E-mail: khaledsayed_1970@yahoo.com

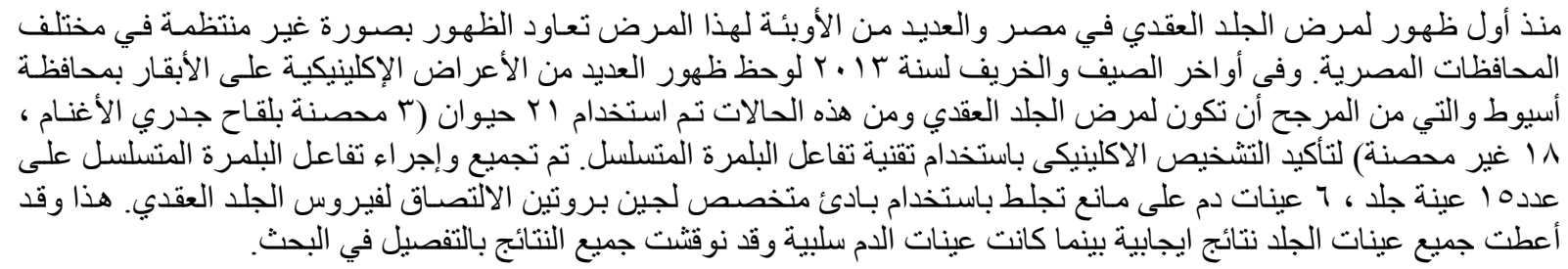

